\title{
ILCEA
}

Revue de l'Institut des langues et cultures

d'Europe, Amérique, Afrique, Asie et Australie

39 | 2020

Les humanités numériques dans une perspective internationale : opportunités, défis, outils et méthodes

\section{Handwritten Marginalia and Digital Search: The Development and Early Research Results of Mill Marginalia Online}

Marginalia manuscrits et recherche numérique: développement et résultats préliminaires de l'édition en ligne de Mill Marginalia.

\section{Albert D. Pionke}

\section{OpenEdition}

\section{Journals}

Electronic version

URL: http://journals.openedition.org/ilcea/8582

DOI: $10.4000 /$ ilcea.8582

ISSN: 2101-0609

\section{Publisher}

UGA Éditions/Université Grenoble Alpes

\section{Printed version}

ISBN: 978-2-37747-174-4

ISSN: 1639-6073

\section{Electronic reference}

Albert D. Pionke, « Handwritten Marginalia and Digital Search: The Development and Early Research Results of Mill Marginalia Online », ILCEA [Online], 39 | 2020, Online since 03 March 2020, connection on 10 October 2020. URL : http://journals.openedition.org/ilcea/8582 ; DOI : https://doi.org/10.4000/ ilcea.8582

This text was automatically generated on 10 October 2020

(c) ILCEA 


\title{
Handwritten Marginalia and Digital Search: The Development and Early Research Results of Mill Marginalia Online
}

\author{
Marginalia manuscrits et recherche numérique: développement et résultats \\ préliminaires de l'édition en ligne de Mill Marginalia.
}

Albert D. Pionke

1 Victorian Britain's leading philosophical empiricist and liberal theorist-and, perhaps the dominant figure in Victorian intellectual life from the 1860s, when he was elected to Parliament as Liberal Member for Westminster, through the 1880s, the decade after his death in which intellectuals in a variety of fields continued to define themselves with respect to his legacy-John Stuart Mill authored significant works on logic, epistemology, political economy, aesthetics, and social reform. In addition, as the de facto editor of the London and Westminster Review from 1836 through 1840 and a frequent contributor to the Westminster Review, Fraser's Magazine, the Edinburgh Review, Tait's Edinburgh Magazine, and other periodicals for the majority of his adult life, Mill was a prolific author of articles, editorials, and review essays. Well known to his contemporaries and central to cultural and social historians of the period, his published writing remains a relevant and frequently cited authority for contemporary university students, philosophers, political theorists, and even elected officials.

2 Less widely recognized is the fact that Mill also left behind a significant body of unpublished writing, in the form of handwritten marks and annotations made on the flyleaves, endpapers, and printed pages of his personal library. Stored in his London residence in Blackheath, this roughly 2000-volume collection was bequeathed to Oxford University's Somerville College in 1905. Acting at the suggestion of Liberal politician John Morley, Miss Mary Taylor, the niece of Mill's step-daughter, Helen Taylor, arranged for the donation of the books without condition to the fledgling college. Once unfortunately thinned of duplicates and of titles thought unsuitable for intellectual 
young women (including, apparently, cook books), the collection was catalogued and placed on open shelves in the newly-built college library, where it served as a significant resource in philosophy, political economy, law, Classics, and English and European literature for female students otherwise barred from taking degrees and entering the university's main research library. These restrictions gradually relaxed during the interwar years, but the books remained in circulation for over six decades, during which some, among them John Stuart Mill's personal copy of Utilitarianism, disappeared. In the 1960s, scholarly interest in Mill revived, spearheaded by the University of Toronto Press edition of the Collected Works; the general editor, $\mathrm{J}$. M. Robson, and his colleagues were meticulous in tracing textual variants, including those discovered in the "SC," or Somerville Collection. By 1969, recognizing that it possessed a unique archive in need of conservation, the college withdrew Mill's books from the stacks and reassembled them into a special collection, presently consisting of 1694 volumes and 45 unbound pamphlets.

3 Although the reconstituted collection attracted a small number of scholars over subsequent decades, Frank Prochaska's 2013 publication of “Mill and Emerson: Sense and Nonsense" in History Today catalyzed Somerville's renewed investment in Mill's library. ${ }^{1}$ The college issued a public call in the November 2014 issue of Somerville Magazine "to foster research into the annotations and to preserve the collection," and obtained two significant results: 1) the formation of the Friends of the John Stuart Mill Library Society, which in its initial phase succeeded in raising over £20,000 for conservation of the physical books; and 2) the launch of Mill Marginalia Online (hereafter MMO), an international collaboration between Somerville College and The University of Alabama whose purpose is to digitize all handwritten marks and annotations in the John Stuart Mill Collection. As the founding director and principal investigator of MMO, I shall provide an overview of the organic development, technical approach, and present scope of this publicly accessible Digital Humanities initiative. I shall then concentrate upon the specific marks and annotations found in Mill's personal copies of Alexis de Tocqueville's De la Démocratie en Amérique (1835-1840) and Auguste Comte's collected works, including Cours de Philosophie Positive (1830-1842) and Système de Politique Positive (1851-1854), to suggest the intellectual significance of Mill's marginalia for international scholarship.

\section{Making Mill Marginalia Online}

Initial development of MMO required an environmental scan of contemporary research. Once the province, peccadillo even, of editors and bibliographers, marginalia has been making a comeback as an object of widespread scholarly attention and has become an increasingly attractive target for digitization. Two examples of such in-process efforts with special relevance for this project during its initial design phase were Charles Darwin's Library, one component in the massive Biodiversity Heritage Library, and Melville's Marginalia Online, hosted by Boise State University.

5 Charles Darwin's Library, with the support of the JISC in Britain and the NEH in the United States, offers "a digital edition and virtual reconstruction of the surviving books owned by Charles Darwin," and includes the full texts of individual books, some of which have authorial marks and annotations. Each page of each book is represented by a digital image, and those pages with marginalia are accompanied by a transcription 
pane that records the location and contents of all verbal and nonverbal inclusions. The website interface allows users to search within its transcribed annotations for words and phrases, and the Biodiversity Heritage Library of which it is a part further enables searches for scientific names across all of its components. However, as a direct result of the metadata and database format chosen for the project, Charles Darwin's Library does not provide for a way to search within the nonverbal marginalia, even though these may indicate serious intellectual engagement with the original printed text. Users interested in, for instance, Darwin's patterns of underlining, marginal check-marking, or even doodling must collect such data on their own by reading through tens of thousands of individual pages.

6 Melville's Marginalia Online, funded by the NEH and the Gladys Krieble Delmas Foundation, includes "an electronic catalog of books owned and borrowed by American author Herman Melville, and a digital edition of marked and annotated books that survive from his library." Like the Darwin site, it provides digital images of every page in every book from its corpus. Unlike the Darwin site, it permits users to filter out books with marginalia, and within each book, it differentiates between pages with marginalia and those without. Digital page images with marginalia appear alongside an apparatus that locates and transcribes all marks and annotations, and that occasionally provides editorial commentary illuminating the significance of particular examples. However, as Elli Bleeker notes in issue 3 of RIDE, "the content [...] could benefit from a better search engine," one in which "the types [of nonverbal marginalia] were indexed or searchable" (2015: para. 16, 20). In fact, the Melville site does not permit searching across its transcribed marginalia, which means that users must work manually through every book in the archive if they wish to make original arguments about Melville's verbal annotations or nonverbal marks. Moreover, he observes, "neither the XML-file nor other underlying raw data are available to the public" (2015: para.24). Nevertheless, Bleeker asserts, "the concept of Melville's Marginalia Online is fascinating and of great interest for academia, and it is worth insisting upon the nonprofit, long-term status of the project" (2015: para. 27).

7 As digital re-collections of personal libraries since dispersed over time, both Charles Darwin's Library and Melville's Marginalia Online succeed in making the marginalia of their respective authors available to an unprecedented audience; however, as quickly became clear to the members of the interdisciplinary project management team for MMO, both also exemplify the limited search capacities of current digital archives. ${ }^{2}$ What we sought to do was to design a site that would enhance the search functions already demonstrated by the Darwin site-by allowing users to search all digital examples of marginalia by type (i.e., score, dash, text, strikethrough), for instance-and emulate some of the more appealing visual elements of the Melville site, which features images of books spines as virtual analogues for material books and careful integration between its page images and editorial apparatus. Self-consciously reversing the hierarchies that underlie both TEI and conventional library cataloguing, we were determined to assign marginalia the role of primary artifact rather classifying it as the secondary attribute of the book in which it appears, thus foregrounding the moment of human/book interaction and seeking to replicate that moment of handwritten engagement through a highly flexible human/computer database and interface. Practically, this meant digitizing only those pages containing marginalia and offering users links to previously scanned digital copies of the same editions provided by sites such as HathiTrust. We also sought to proleptically avoid the issues of technical 
approach and transparency noted by Bleeker by building a more robust and accessible database and search architecture.

The project's initial dataset was quite small, consisting of the results of a single research trip undertaken in July 2015-roughly 900 page images from 25 of what seemed the most promising volumes from throughout the library- and the general assumption was that the overall collection contained perhaps hundreds examples of marginalia. As my team at the University of Alabama Digital Humanities Center began to create a metadata schema capable of documenting both verbal annotations and nonverbal marks and a database format that would render this information amenable to multi-faceted searching, Somerville secured funds from the Gladys Krieble Delmas Foundation to hire a postdoctoral researcher to conduct a census of all marginalia in the collection. Her work, and three subsequent data-gathering trips, made it clear that there were tens of thousands, not hundreds, of handwritten additions to the books, made in a diversity of hands, materials, and forms that would require an entirely different economy of scale to record, visualize, and search.

Our initial plan had been to build one of the first examples of a scholarly humanities interface using a noSQL database, which, because it arranges its content using nested objects and attributes rather than relational tables, greatly reduces the time and expense of enlarging the dataset, updating the metadata schema, and allowing for future changes to the archive or to its computational infrastructure. With the potential for so many searchable objects, however, this purely noSQL approach grew unfeasibleusers would have faced unreasonable wait times and excessive downloads with every search-and so my technical team settled upon a hybrid of a SQL and noSQL database, one that capitalizes upon the former's speed in filtering and querying and the latter's flexibility and ease of updating. Thus, a simple differentiation between verbal and nonverbal forms of marginalia is married to a JSON field containing a readily expandable set of categories and subcategories that both allows for more precise identification of the myriad types of marginalia found in the Mill Library and accommodates the discovery of new forms of marginalia as the data is collected. ${ }^{3}$ This hybrid approach permits such additions without requiring the consequent updating to the pre-existing dataset and large-scale data migrations that would otherwise be necessary in an SQL-only database. ${ }^{4}$

10 At the time of writing, MMO has digitized all handwritten marks and annotations in 328 of the 1694 volumes in Somerville's John Stuart Mill Collection. Including books that were surveyed, but that contain no marginalia, this represents roughly $20 \%$ of the archive, with another $5 \%$ currently being transcribed. Our team has categorized 61 different types and subtypes of handwritten additions, including many that have never before been classified, such as corrugated score (Figure 1), inverted bracket (Figure 2), and word map (Figure 3): ${ }^{5}$ 


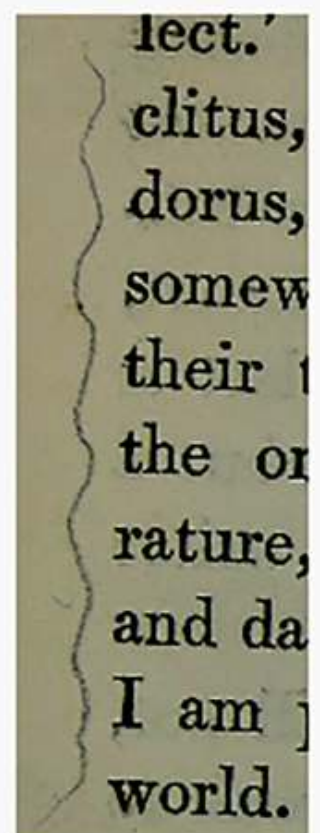

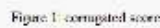

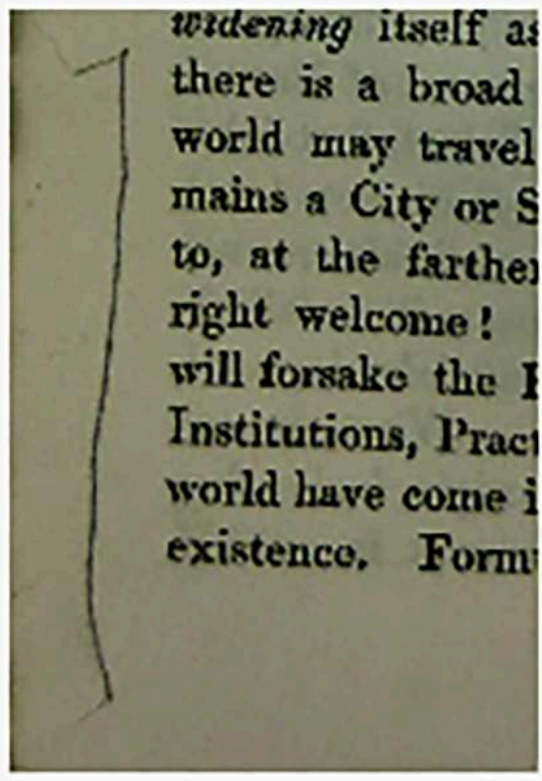

Figure 2: inverted bracket 


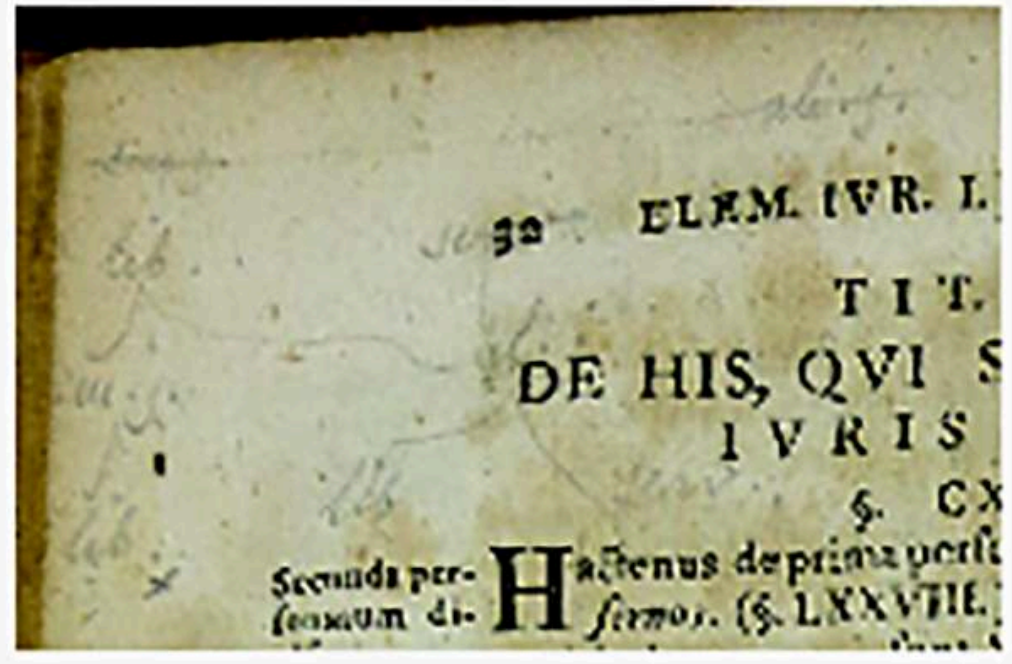

Figure 3: word map

The addition of over a hundred books once owned and annotated by John Stuart's father, James Mill, required us to rethink the way we were classifying marginal additions that we felt confident attributing to either Mill. Previously embedded within the schema of types and subtypes (i.e., Text [JSM's hand]: Numbers), attribution became a source of unnecessary and confusing repetition once we were faced with categorically identical marks made by those whose methods of annotation bore a familial resemblance to each other. We therefore removed all attributions to a separate metadata category, now searchable, resorted the list of types and subtypes, and applied the changes retroactively to the pre-existing data. Illustrating the strength of our hybrid database approach and foregrounding of marginalia as primary organizing principle, these changes were executed without a system crash, a substantial reprogramming of the database or search algorithm, or any loss of previously posted data.

\section{Mill's Marginalia in Alexis de Tocqueville's De la Démocratie en Amérique}

Among the 109 authors of the 328 volumes represented on $M M O$ at the time of writing are two with special relevance for John Stuart Mill's intellectual development and, more broadly, for the transmission of ideas between England and France in the second quarter of the nineteenth century. Mill first encountered the work of Alexis de Tocqueville in the 1830s, when Mill was editing and contributing extensively to the London and Westminster Review, coming to grips with the death of his father, and beginning his initially platonic but still unconventional relationship with Harriet Taylor. He was also reappraising his earlier, relatively uncritical acceptance of "representative democracy as an absolute principle" even as, according to his Autobiography, at the level of "practical political creed," he continued "as much as ever a radical and democrat, for Europe, and especially for England" (1873: CW 1.177). ${ }^{6}$ Mill's 
handwritten marks and annotations in his personal copy of De la Démocratie en Amérique, the second half inscribed by Tocqueville, document his sometimes-skeptical private reaction to his then-friend-and-correspondent's analysis of America's great social and political experiment. A much longer trajectory of reaction and, ultimately, of rejection, is evident in Mill's marginal commentary within the works of French positivist and social theorist Auguste Comte. Mill first encountered Comte's work in the late 1820s, and later "fell in with Comte's Cours de Philosophie Positive, or rather with the two volumes of it which were all that had at that time been published" in 1837 (1873: CW 1.217). He was at first so impressed that he initiated a correspondence and incorporated some of Comte's insights into the first edition of his own System of Logic (1843). Later, as more of Comte's work appeared and the two men disagreed about basic issues of method, the role of women, mandatory subventions for intellectuals, and the increasingly religious cast of Comte's work, their "zeal cooled" and they ceased exchanging letters by 1847 (1873: CW 1.219). Ultimately, Mill sought to give Comte his due, which also included repudiating many of his later positions, in Auguste Comte and Positivism (1865), with the marginalia in his personal copies of Système de Politique Positive (1851-1854) and Synthèse Subjective (1856) in particular testifying to the meticulousness with which he approached this final appraisal.

Qualitatively dense if not quantitatively abundant, Mill's marginal additions to De la Démocratie en Amérique are confined to 36 marks and annotations in the two-volume second part of Tocqueville's work. Mill had already provided the definitive review of the two-volume first part in 1835 for the London and Westminster Review and he was preparing to do the same for the second part in 1840 in the pages of the Edinburgh Review. During the intervening years, Mill has shifted from cultivating Tocqueville as a potential contributor to corresponding with him as a friend and fellow social theorist, one with whose ideas he found himself increasingly in accord.

This is not to say that Mill agreed with all of Tocqueville's assertions, however. Accepting by 1840 the empirically-grounded analysis of the pernicious effects of democracy in the United States-including the dearth of superior leadership and the tyranny of the majority over public and private opinions-advanced in part two of De la Démocratie en Amérique, Mill nevertheless writes in his published review that Tocqueville has "confounded the effects of Democracy with the effects of Civilization. $\mathrm{He}$ has bound up in one abstract idea the whole of the tendencies of modern commercial society" (1840: CW 18.191). Citing the example of Great Britain, a nation in which, "with the single difference of our remaining respect for aristocracy, the America people, both in their good qualities and in their defects, resemble [...] an exaggeration of our own middle class," Mill posits that it is the commercial class's single-minded pursuit of wealth that leads to the worst aspects of democratic society (1840: CW 18.193). In addition to endorsing Tocqueville's call for participation in local politics and voluntary associations, Mill also declares that "in a commercial country" what is needed to counterbalance the overvaluation of wealth and its social consequences is a combination of "an agricultural class, a leisured class, and a learned class" (1840: CW 18.198).

As Mill wrote to his friend in May, while still working on his second review, "it will require much thought \& study to appreciate your ideas so completely as to be qualified to say what portion of them I shall at last feel to be demonstrated \& what, if any, may seem to require further confirmation" (1840: $C W 13.434)$. With its two ampersands, the 
apparent questioning by Mill of his own qualifications, and the rhetorical diminution from "feel" to "seem," this letter is a study in deferred judgment. ${ }^{7}$ In December of that year, with the review published, Mill's relief at the grace with which Tocqueville had received his critique about the conflation of democracy and commerce is discernible in his repetitive word choice: "You may imagine how much pleasure it gave me to find that you were pleased with my review of your Second Part" (1840: CW 13.457). Measuring the work that he put into this second review, Mill goes on to admit, "I know how much thought [the second part] calls for from the reader when I remember how long it was before I could make up my mind about it" (1840: CW 13.458).

In fact, the twenty-five nonverbal marks-which include multiple scores, brackets, plus signs, curly brackets, double scores, and x-marks-and eleven verbal annotations reveal degrees of skepticism about Tocqueville's claims well beyond those in the published review or Mill's private letter, articulated with an unvarnished bluntness that likely would have made his new friend a bit disconcerted if only he had known. Two initial annotations, one from each volume of part two, may help to show why Mill describes himself as still in the midst of "thought \& study" in his May 1840 letter. The first appears in the inner margin of vol. 3, p. 170 alongside a passage in which, speaking as a historical sociologist, Tocqueville attempts to characterize the broad differences between democratic and aristocratic centuries (Figure 4). The former are affected more by what he calls "general facts," whereas the latter take their lead more from "special influences." Conceptually a little imprecise, this distinction tends to minimize the efforts of even extraordinary individuals to influence the "general facts" of democratic life. Certainly, for example, ex-editors of the London and Westminster Review have little hope of turning the national course, which fact, perhaps, contributed to Mill's marginal appraisal: "This is all my eye -."

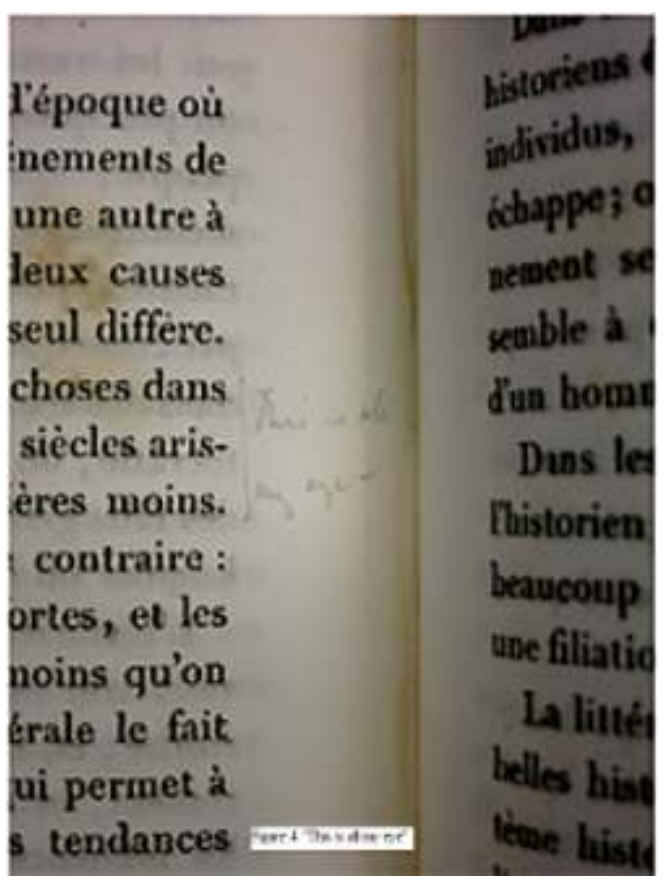

Mill evinces similarly naked incredulity on vol.4, p.113, when Tocqueville defends democratic societies for their superior authenticity. Although individual manners in the average democracy may be a bit basic, people at least behave like themselves 
without feeling the need to emulate their betters, he claims. To this generalization, marked with an emphatic double score, Mill's one-word response is "No -."

Mill's marginal judgments also extend to greater lengths and levels of substance than these examples. For instance, on p. 293 of vol. 3, Tocqueville opines about the unique dangers of materialism in democratic societies (Figure 5). After asserting that it is the responsibility of democratic statesmen and intellectuals to continuously remind their self-improvement-obsessed countrymen of the greater rewards of heaven, he labels as "enemies of the people" all those who profess disbelief in the immortality of the soul. A confirmed atheist who nevertheless thought of himself as a Radical advocate for the demos, Mill might well feel himself painted with an unfairly broad brush here. His response, however, is not defensive dismissal, but rather logical objection. After registering his confusion with a question mark, he wonders, "Why of this [?] / only - if of th[?] / people, of all - [?] / not of all, of no[?]." Although a subsequently over-eager page-edge trimmer has unfortunately deprived us of the totality of Mill's remarkshence the bracketed question marks-we can, without unwarranted speculation, infer that Mill doubts the logical sufficiency of a deductive argument whose first principle, that materialists are the enemies of the people, is applicable only in certain circumstances.

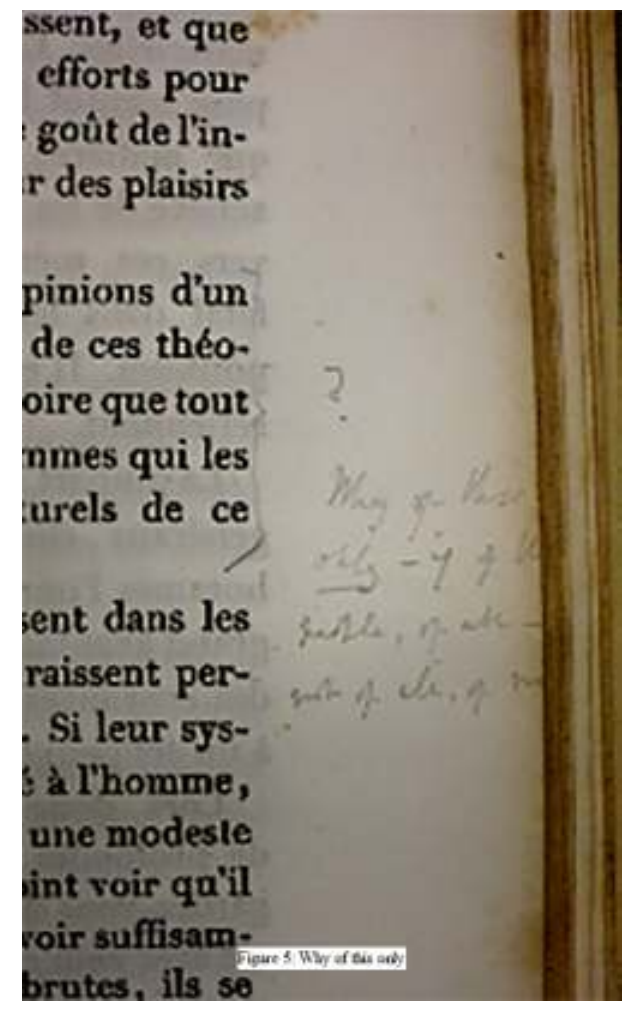

Later in volume three, on p. 323, Mill even questions the basic truth value of another of Tocqueville's assertions, this one about what we might call vocational determinism (Figure 6). In a paragraph that anticipates by over a decade Ruskin's critique of the dehumanizing effects of industrialized labor in "The Nature of the Gothic" and by nearly forty years Morris's ethical distinction between "Useful Work and Useless Toil," Tocqueville writes of the degrading effects of a life "making heads for pins." Such a worker, he says, "no longer belongs to himself" but to his "vocation," which acts as an insuperable barrier to his pursuit of the "thousand different paths to fortune" that democratic "laws and manners" have made available to him. Mill's response is a 
categorical rejection-“"All this, mu[?] / be taken wi[?] / great reserv[?] / It is not $\operatorname{tr}[$ [? / as here state[?]"-discernible enough despite the missing outer margin.

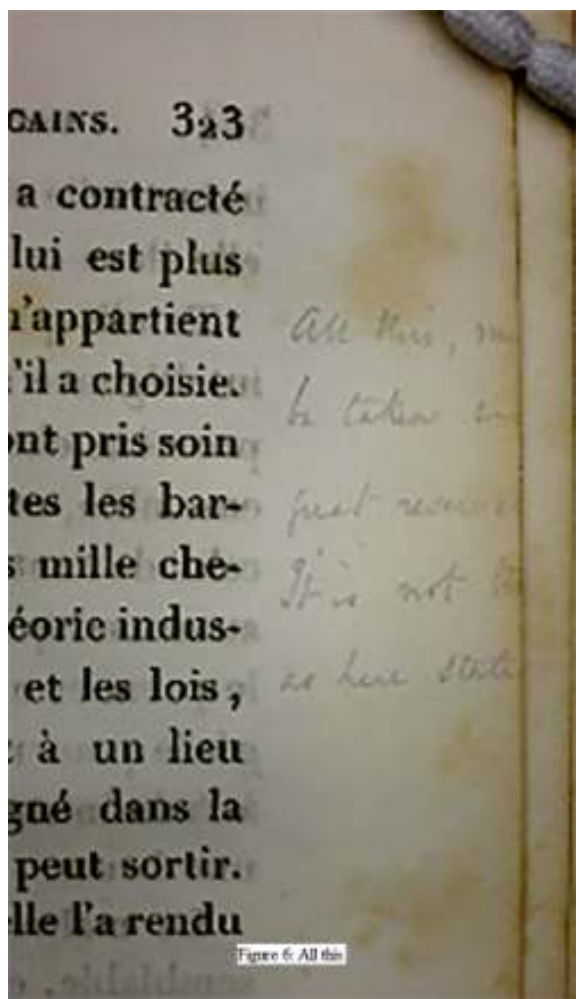

What we cannot know is whether Mill's doubts here are rooted in his empiricism, his radicalism, or some combination of the two. What is clear is that this particular "great reservation" never made it into the 1840 review essay, although it may be one reason why Mill's third published paragraph begins with the rather odd assertion that, "The importance of M. de Tocqueville's speculations is not to be estimated by the opinions which he has adopted, be these true or false" (1840: CW 18.156).

In addition to his marginal marks and rather cramped annotations, presumably made simultaneous to the initial act of reading, Mill occasionally writes more summative reflections at the ends of chapters or sections. For instance, at the end of vol.4, chap. 14, "Some Reflections on American Manners," Mill appends a lengthy note registering his empirical objection to the Frenchman's ignorance of English culture (Figure 7): 


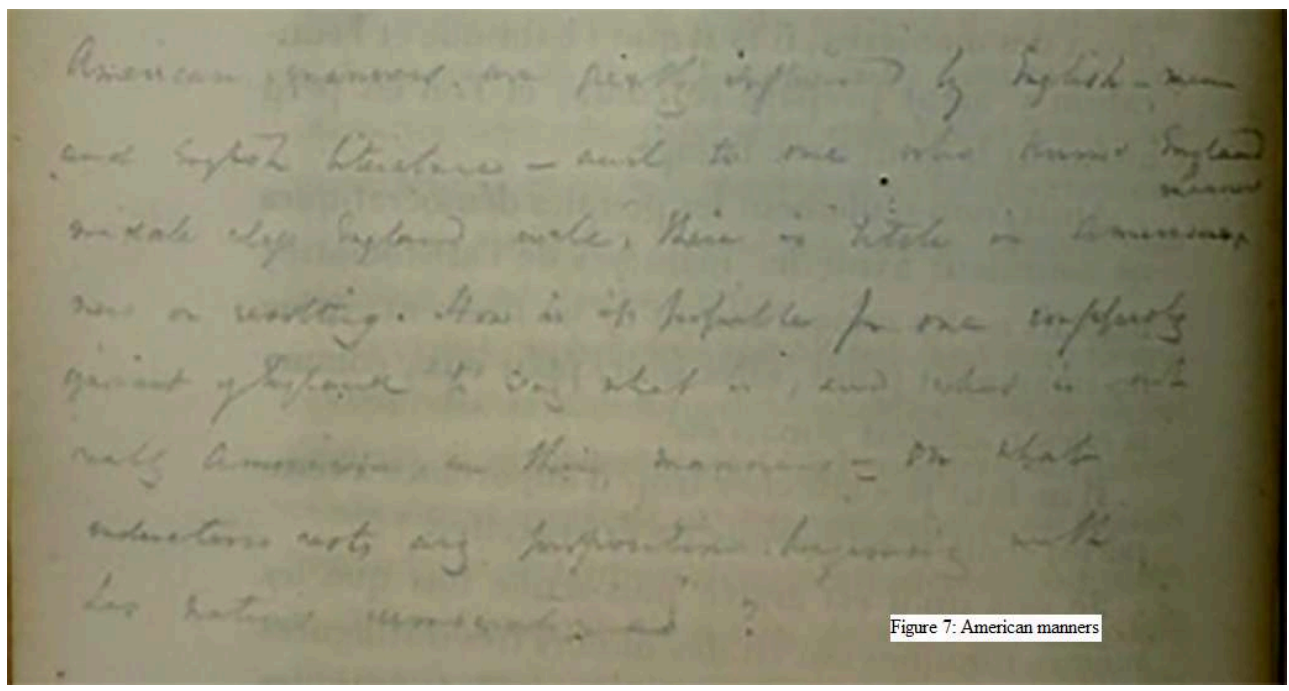

American manners are greatly influenced by English men

and English literature - and to one who knows England middle class England well, there is little in American manners new or revolting. How is it possible for one confessedly ignorant of England to say what is, and what is not, really American, in their manners - on what induction rests any proposition beginning with "Les nations démocratiques"?

Here we can see the argumentative basis for Mill's published critique that Tocqueville has confused the effects of commercialization with the consequences of democratization. Moreover, in this marginal comment lies the germ of Mill's subsequent comparison of "the American people" and Britain's "own middle class"; although, for his published remarks, Mill removed all mention of Tocqueville's "confessed ignorance" and did not question his friend's powers of induction.

Mill saw clear similarities between Americans and Britons, not only in the present, but also projected into the future. On the back flyleaf of vol. 4 of Democracy in America is a neatly penciled annotation that imagines an even closer convergence of manner between English speakers on both sides of the Atlantic (Figure 8). Almost certainly written after reviewing his own marginal first reactions to Tocqueville's text, the note begins with a page reference tied to an earlier nonverbal mark on p. 128. In what would come as no surprise to nineteenth-century British readers, Tocqueville characterizes Americans as thin-skinned and quick to take offense in response to criticism. Mill originally marked this passage only with a marginal double score. When he returned to it later, Mill displayed a caustic humor that may surprise those accustomed to the measured reasonableness of his mature publications: 


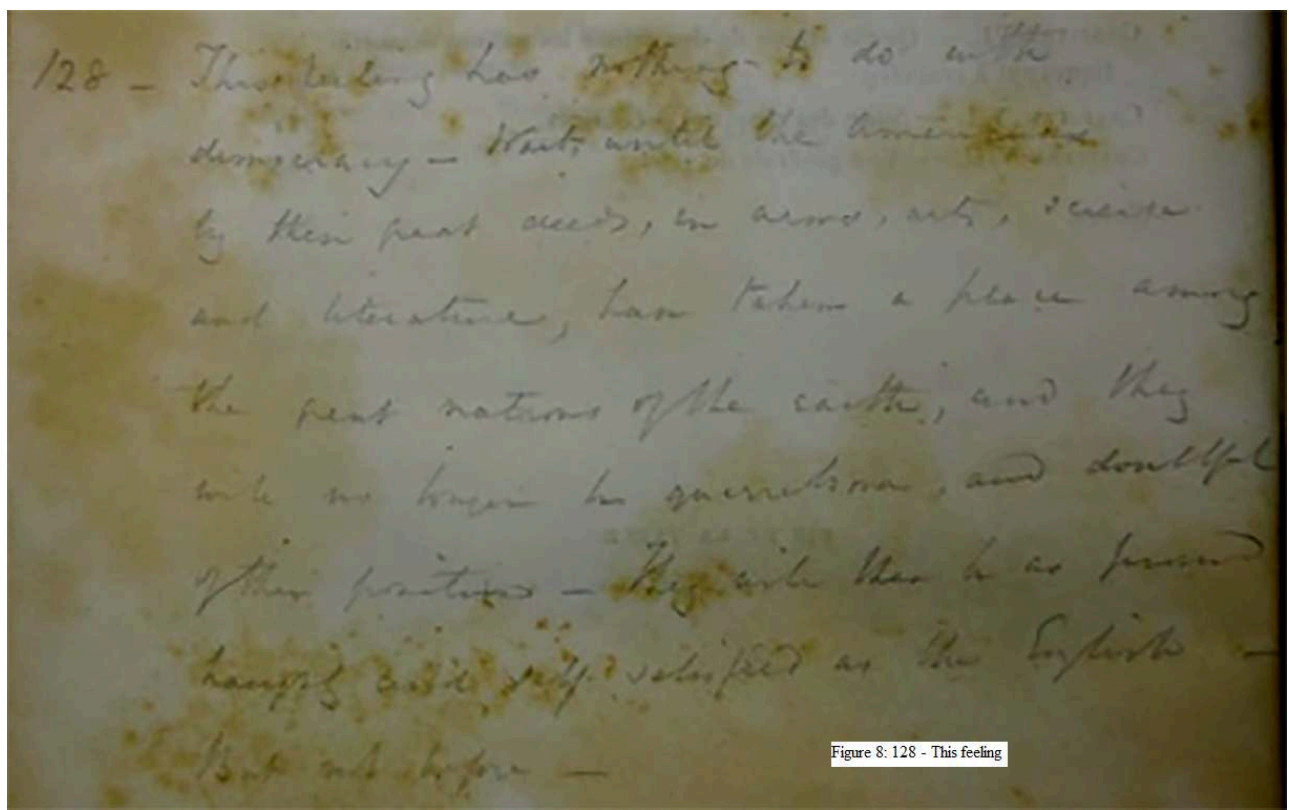

128 - This feeling has nothing to do with democracy - Wait, until the Americans by their great deeds, in arms, arts, science and literature, have taken a place among the great nations of the earth, and they will no longer be quarrelsome, and doubtful of their position - They will then be as proud haughty and self satisfied as the English But not before -

It's hard to tell whether the "insatiably vain" Americans or the "haughty and selfsatisfied" British middle classes come off worse in this annotation.

That these examples of Mill's reactions during and after his "study" of Tocqueville remain largely unknown is not just a consequence of their presence in a special collection kept behind locked doors in Oxford, but also a function of Mill's practices of reading. Judging from the verbal and nonverbal marks in his copy of De la Démocratie en Amérique, Mill read the book, pencil in hand, making marks and cramped annotations and along the way. Although the intent of the former is sometimes hard to gauge, the latter seem almost entirely motivated by local disagreement with the text under review. Once he had finished this preliminary markup, Mill appears to have gone through the book again, writing more expansive responses in a cleaner hand and establishing the argumentative foundation, although not the actual phrasing, for what would become his published review. Like those of his contemporaries, Mill's reviews would frequently include lengthy quotations from the original text; interestingly, in the case of his 1840 review of De la Démocratie en Amérique, none of the excerpted passages is one that Mill had himself marked while reading.

\section{Mill's Marginalia in Auguste Comte's Works}

A very different pattern of marginal annotation appears throughout the numerous books authored by French positivist, social theorist, and founder of modern sociology, Auguste Comte, and kept by Mill in his library at Blackheath. Somerville's John Stuart Mill Library collection includes Comte's Cours de philosophie positive (1830-42), an 
inscribed copy of Traité élémentaire de géometrie analytique à deux et trois dimensions (1843), an inscribed copy of Traité philosophique d'astronomie populaire (1844), an inscribed copy of Discours sur l'ensemble du positivisme (1848), Système de politique positive (1851-54), Catéchisme positiviste (1852), Appel aux conservateurs (1855), and Synthèse subjective (1856). All contain marginalia, which has been fully digitized, transcribed, and published to MMO. In total, 685 pages spread across these eight titles and seventeen volumes contain 917 individual examples of marginalia.

Unlike in Tocqueville's De la démocratie en Amérique, however, in which just over $30 \%$ of the marginalia is composed of verbal annotations, some quite lengthy, less than $5 \%$ of the marginalia in Comte's works is verbal, with all of that definitively attributable to Mill consisting of brief editorial corrections. The most substantive additions appear in Traité élémentaire de géometrie analytique à deux et trois dimensions, wherein Mill, presumably while still in his early phase of admiration for Comte, had detected and subsequently corrected "a considerable number of typographical errors [...] among the equations" (1843: CW 13.579-82). ${ }^{8}$ The remaining $95 \%$ of the marginal nonverbal marks are distributed unequally, with the four-volume Système de politique positive and much shorter one-volume Synthèse subjective featuring roughly $63 \%$ and $19 \%$ of the total, respectively.

Thus, over $80 \%$ of the marginalia inscribed within Comte's works were made after the two men's dramatic falling out in the latter half of $1845 .{ }^{9}$ Judging from Mill's marginalia in other books, whether those by Thomas Carlyle-with whom Mill had a similarly contoured relationship: early admiration, followed by an intense correspondence, which exposed fundamental disagreements that led to a personal and intellectual distancing-or the volumes of Emerson's Essays discussed by Prochaska, Mill tended to cease annotating once he had decided that he could no longer learn anything useful from a text. ${ }^{10}$ According to his Autobiography, Mill judged Comte's Système de politique positive "the completest system of spiritual and temporal despotism, which ever yet emanated from a human brain," and so it should, perhaps, come as little surprise that he did not verbally engage with it any more than necessary (1873: CW 1.271).

As when reading the Tocqueville, however, Mill was committed to writing a review of Comte's work. It is impossible to know for certain when the many hundreds of nonverbal marks were inscribed in the margins of Comte's books, but it seems reasonable to assume that most were made in the first half of the 1860s, when Mill turned from his Examination of Sir William Hamilton's Philosophy (1865) to a comprehensive overview of the contributions of Comte to European intellectual history. ${ }^{11}$ Solicited by John Chapman, the editor of the Westminster Review, to write such a response as early as 1851, Mill had demurred responding publicly while either Comte or Harriet Taylor-Mill still lived. By 1864 both had died and Emile Littré, who was both Comte's disciple and one of Mill's French correspondents, had published a second edition of Cours de philosophie positive; this combination of circumstances provided Mill with the opportunity to agree to Chapman's longstanding request. ${ }^{12}$

Auguste Comte and Positivism appeared first in 1865 as a pair of articles in the Westminster Review; these were very lightly corrected and bound together into a single volume, which appeared in print before the end of the year. It begins benignly, recognizing Comte for his groundbreaking systematization of positivist thought, his tripartite stage theory of scientific development, his hierarchy of the sciences according to their historical development and necessary intellectual subordination to one another (1865: 
$C W 10.264-79)$. However, the tone shifts relatively quickly, since, according to Mill, the rise in Comte's reputation since the original publication of his Cours de philosophie positive and early struggles at the École Polytechnique have, according to Mill, "rendered it, for the first time, not inopportune to discuss his mistakes" (1865: CW 10.264). These become the subject of the lengthier second half of the review, wherein they turn out to be both numerous and serious, and include errors of methodology, logic, standards of proof, and what we might call disciplinary knowledge, as Mill fault's Comte's grasp of psychology and political economy. ${ }^{13}$ The Religion of Humanity Mill pronounces "really ludicrous" (1865: CW 10.327), Comte himself "a morality-intoxicated man" filled with "self-conceit" (1865: CW 10.336, 331), and his general authoritarianism and specific prescriptions regarding childhood education "deplorable" (1865: CW 10.356).

31 The evidence for Mill's pejorative judgments come overwhelmingly in the form of citations from Comte's works. Adding together Mill's acknowledged quotations with further direct references identified by Robson and his fellow editors, I have counted eighty-nine references on forty-five separate pages of Auguste Comte and Positivism. All correspond to page numbers from the editions of Comte's works held by Somerville College and digitized on $\mathrm{MMO}$, and roughly $40 \%$ connect back to pages containing one or more examples of handwritten marginalia. This correspondence suggests that Mill went back through the many hundreds of marks that he made while rereading Comte's works in preparation for his review and selected those he thought would provide him with the best example of whatever "mistake" he found it necessary to discuss. The rate at which Mill cites Comte increases from the more neutral part one ( 0.38 citations per page) to the more critical part two (1.56 citations per page) of his review, as does the overlap between citations and marginal marks in part one (12\%) and part two (52\%), providing further empirical evidence for this supposition.

The density of citations, and the rate at which these correspond to marginalia in Mill's personal copies of Comte's published works, are especially striking in that section of part two of Auguste Comte and Positivism dedicated to discussing Synthèse Subjective. These six pages feature fifteen citations, a rate of 2.5 per page, all but two of which (87\%) correspond to marginalia found in Mill's own copy. ${ }^{14}$ Page 366 in the Collected Works is typical in containing three identified references to Comte's later work, all of which correspond to nonverbal marginalia in Mill's personal copy. At the top of the page, Mill provides a lengthy paraphrased translation of Comte's veneration of prime numbers, especially the number thirteen. The paragraph in which this somewhat labored numerology originally appeared is at the top of p.111 in Comte's Synthèse subjective; precisely in the middle of the outer margin of this partial paragraph is a hand-written plus sign (Figure 9): 
subjective que quand la synthèse finale aurait rendu relative une notion toujours jugf́e absolue. Une juste appréciation de l'ordinalité suffit pour introduire entre eux une distinction susceptible de degrés indéfinis, en les qualifiant de doublement premiers quand leur rang est premier, et dès lors triplementpre. + miers si lui-même est doublement premier, ainsi de suite. Mais l'aptitude subjective dolt surtout appartenir au début d'une telle hiérarcbie; sept et treise y deviennent prépondérants, comme étant les plus petits des nombres doublement et triplement premiers, sauf les nombres sacrés, oú cet attribut n'a pas de bornes.

Figure 9: Comte's Synthese Subjective, p. 111

Further down the same page of his 1865 review, Mill censures Comte's "frenzy for regulation," citing his belief that "l'arbitraire is always favourable to egoism." This specific phrase appears within a longer passage on p. 107 of Synthèse subjective advocating in favor of the numerical regulation of every facet of human life; here, too, the outer margin features a penciled plus sign (Figure 10):

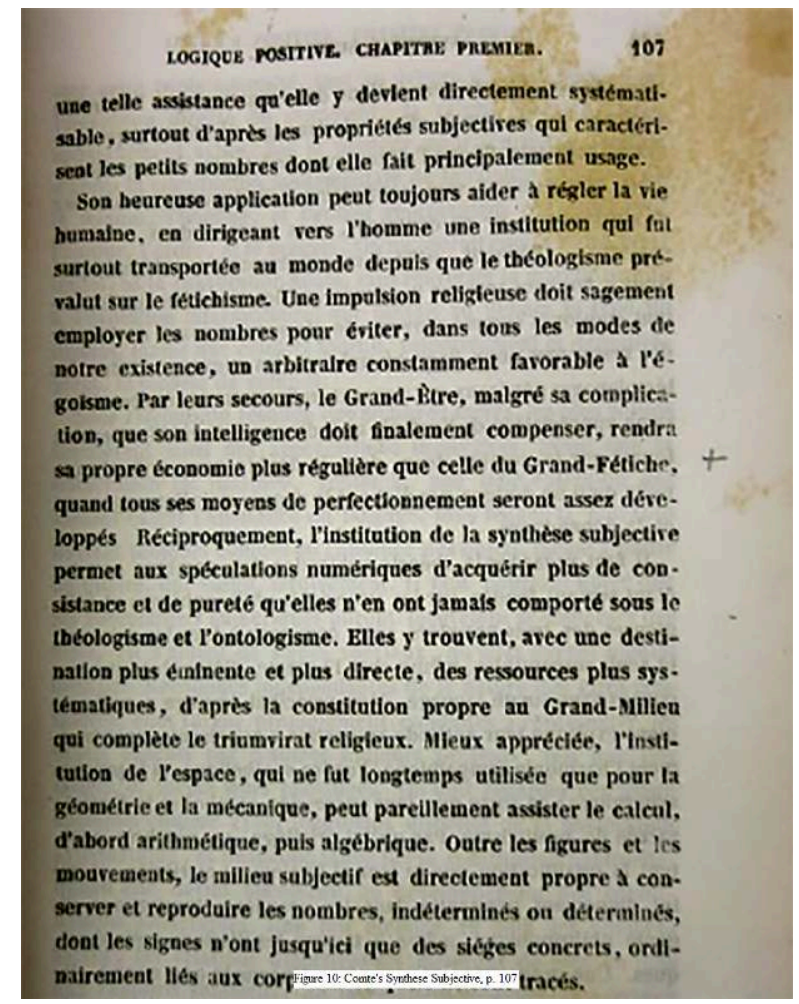

34 Mill goes on to explain how Comte's desire for quantifiable regularity has led him to meticulously regulate his own prose. The rules that Mill proceeds to enumerate come from a section that begins with another paragraph marked with a marginal plus sign, this time on $\mathrm{p}$. IX of the preface to the fourth volume of Comte's Système de politique positive (Figure 11): 


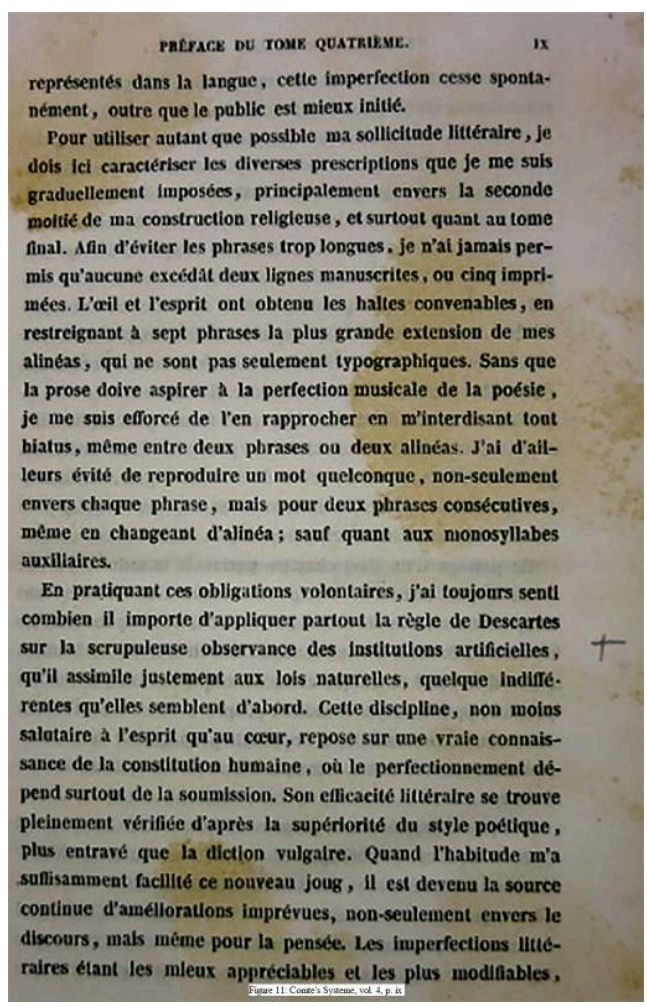

Unlike in his review of Tocqueville, then, Mill goes out of his way to cite passages that he views as evidence for the shortcomings in Comte's thinking. Moreover, these passages are not accompanied by the kind of verbal analysis and sometimes constructive disagreement that appears in De la Démocratie en Amérique, but are instead much more simply marked, most often with plus signs and x-marks, as evidence worthy not of further intellectual debate but instead of exemplary citation. Mill arguably did more than anyone else to introduce his countrymen to the ideas of both Tocqueville and Comte. His reviews of 1835 and 1840 elevated Tocqueville's concerns about "the tyranny of the majority" and the tension between liberty and equality to the forefront of subsequent debates over the character of England's emerging democracy. And, as he himself recognized in his Autobiography and as subsequent historians of sociology have endorsed, Mill "contributed more than any one else to make [Comte's] speculations known in England. In consequence chiefly of what I had said of him in my Logic, he had readers and admirers among thoughtful men on this side of the Channel at a time when his name had not yet, in France, emerged from obscurity" (1873: CW I.271). However, as the marginalia in his personal copies of both men's work attests, Mill initiated this intellectual leavening of British intellectual history with radically different methods of reading and annotation.

Of the over 100 additional authors already digitized on $M M O$, the works of more than two dozen contain enough marginalia to merit a closer look. Included among them are books written by similarly significant figures in intellectual history-Francis Bacon, Thomas Hobbes, David Hume, John Locke, Henry Maine, David Ricardo, Adam Smith, Herbert Spencer, Richard Whatley-as well as slightly lesser luminaries with special relevance to James and/or John Stuart Mill. ${ }^{15}$ Moreover, with a dataset already containing over 11,000 individual examples of marginalia, MMO offers those with research interests in bibliography, paleography, linguistics, periodical studies, literacy practices, aesthetics, and other humanities fields a statistically sufficient number of 
searchable examples on which to construct empirical arguments. To cite only one possibility, check marks, plus signs, double scores, et al. represent a bank of symbols with potentially no less representative value than today's myriad emojis; what has been lacking until now has been a large enough sample size of marks to decode. In addition, MMO provides users with the capacity to download raw photos and project metadata directly from the site, and we have posted the database programming to github. And the number and variety of examples-of authors, of digitized texts, of marginalia types, and of images-will continue to grow over the next five years, at the end of which we hope to have completed the digitization and transcription of the roughly 45,000 total instances of handwritten marks and annotations found throughout the collection. Whether they are invested in Mill and his circle or more broadly in making searchable their own data sets of paratextual additions, future humanities researchers will be able to reuse, adapt, and further develop the tools we have created for use on their own digital projects.

\section{BIBLIOGRAPHY}

ALEXANDER Edward (1969), “Mill's Marginal Notes on Carlyle's 'Hudson's Statue”, ELN, 7, 120-23.

BLEEKER Elli (2015), “Review of 'Melville's Marginalia Online.”, RIDE: A review Journal for digital editions and resources, 3, <http://dx.doi.org/10.18716/ride.a.3.1>.

MiLL John Stuart (1963-1991), The Collected Works of John Stuart Mill (33 vols), J. Robson et al. (eds), Toronto, Ontario: University of Toronto Press.

MUELLER Iris Wessel (1956), John Stuart Mill and French Thought, Urbana, Illinois: University of Illinois Press.

PionkE Albert D. \& WiLson Emma Annette [eds] (2018), Mill Marginalia Online, $<$ www.millmarginalia.org $>$ (28 December 2018).

ProchaSKA Frank (2013), “Mill and Emerson: Sense and Nonsense," History Today, 63(9), 21-26.

RyAN Alan (1990), The Philosophy of John Stuart Mill ( $2^{\text {nd }}$ ed.), Atlantic Highlands, NJ: Humanities Press International.

SIEGEL Erik \& RETTER Adam (2014), eXist: A NoSQL Document Database and Application Platform, Sebastopol, United States: O'Reilly Media.

\section{NOTES}

1. Alexander (1969) published a brief account of Mill's notes within Thomas Carlyle's Hudson's Statue, and Dr. Robert Fenn visited the library in the 1980s with the intention of transcribing all handwritten marks and annotations made by James Mill. Fenn's his unpublished notes remain in the possession of Somerville College and have been used to check transcriptions and attributions for MMO. 
2. Initial members of the team responsible for conceptualizing, designing, and implementing MMO were, in addition to myself, Emma Annette Wilson, Assistant Professor of English, Digital Scholarship Librarian, and Director of the University of Alabama Digital Humanities Center; Tyler Grace, IT Technical Specialist II; and Mary Alexander, Metadata Librarian. The project continues to be hosted and maintained by UA's Digital Humanities Center, whose present Director, Anne McDivitt, and IT Technical Specialist, James Michelich, provide its technical support-including resolving glitches that result from an increased and increasingly diverse data set, maintaining the site's compatibility with major web browsers, and adding to the site's data filters and other functions. I manage the site's content, which includes consulting with metadata librarians as needed about new marginalia types, as well as with experts in paleography, hyperspectral imaging, the history of philosophy, and the at least five languages other than English (French, German, Italian, Greek, Latin) with which Mill was conversant. The project's primary international collaborator is Dr. Anne Manuel, Archivist and Librarian at Somerville College. In both the United States and the United Kingdom, students at all levels have provided invaluable research assistance. All contributors are listed on the "Credits" page of MMO.

3. JSON (JavaScript Object Notation), a lightweight data-interchange format that is easy both for humans to read and for machines to parse and generate (json.org). Many of the world's APIs (Application Programming Interfaces), already use JSON to facilitate human: computer and computer: computer interactions, meaning that the data generated by this project will require no further adaptation to make it available for a variety of future applications.

4. See Seigel \& Retter (2015) for a comprehensive explanation of the technical advantages of a noSQL approach.

5. All images have been taken with permission from MMO.

6. All citations from John Stuart Mill's published works will be made from Mill (1963-1991), with parentheticals referencing the Collected Works $(\mathrm{CW})$ by volume and page number.

7. As Iris Mueller notes, "It is interesting to contrast the mild tone with which Mill expressed his differences in the letter to de Tocqueville with the far more definite expression of public pronouncement" (1956: 135n5).

8. I have adopted Haac's translation on pp. 146-49.

9. On the specifics of their falling-out, see $C W 13.646-48$ and $677-79$, translated by Haac on pp. 266-69 and 328-30.

10. It is worth noting that after Emerson's essay on "Friendship" in his second series of Essays, Mill ceased to write annotations, even of the pejorative sort ("Stupid", "Very Stupid") discussed by Prochaska. He had, apparently, reached his limit and decided to save his intellectual outrage for someone who deserved the effort to express it.

11. Within his letters, after 1848 Mill never writes to any correspondent that he has just finished or is in the process of reading any of Comte's works as they appear, providing further indirect evidence reinforcing the idea that the marginalia found within Comte's later works was made all at once, while Mill was engaged in his review.

12. Robson's textual introduction to volume ten of the Collected Works carefully traces the correspondence concerning and publication history of Auguste Comte and Positivism, identifying relevant letters to Chapman, Harriet Mill, Alexander Bain, Herbert Spencer, and George Grote written between 1851 and 1865 ( $C W 10 . c x x x-C X x x I V)$.

13. On the basis of the problem Mill discovers in Comte's disciplinary knowledge of psychology and political economy, see Ryan (1990: 156).

14. These statistics were calculated by hand after a line-by-line comparison of Mill's marginalia and Comte's text.

15. The marginalia in Mill's considerable collection of European literature has yet to be fully digitized. Researchers with specific interests in French or German literature, as opposed to 
philosophy, jurisprudence, or political economy, are invited to check back with MMO for future updates.

\section{ABSTRACTS}

Victorian Britain's leading philosophical empiricist and liberal theorist, John Stuart Mill left behind a significant body of unpublished writing, in the form of handwritten marginalia within the books of his personal library. Mill Marginalia Online is an international Digital Humanities collaboration between The University of Alabama and Somerville College dedicated to producing a digital edition of this material. This ongoing project's organic development, technical approach, and present scope may serve as a useful model for future DH initiatives. Its actual content, as represented by the marks and annotations present in Mill's personal copies of Alexis de Tocqueville's De la Démocratie en Amérique (1835-40) and Auguste Comte's collected works, including Cours de Philosophie Positive (1830-42) and Système de Politique Positive (1851-54), begin to suggest the intellectual significance of Mill's marginalia for international scholarship.

John Stuart Mill, grand théoricien libéral et philosophe britannique de l'époque victorienne aux méthodes empiriques, a laissé derrière lui un important corpus d'écrits non publiés, sous la forme de marginalia notés à la main sur les livres de sa bibliothèque personnelle. Mill Marginalia Online est une collaboration internationale en humanités numériques entre l'Université de l'Alabama et le Somerville College qui se consacre à la production d'une édition numérique de ce matériel. Le développement organique, l'approche technique et la portée actuelle de ce projet en cours peuvent servir de modèle utile pour de futures initiatives dans le domaine des humanités numériques. Son contenu, à l'instar des marques et annotations présentes dans les copies personnelles d'Alexis de Tocqueville De la Démocratie en Amérique (1835-1840) et dans les œuvres d'Auguste Comte, dont Cours de Philosophie Positive (1830-1842) et Système de Politique Positive (1851-1854), est le signe de la pertinence intellectuelle des marginalia de Mill pour la recherche internationale.

\section{INDEX}

Mots-clés: John Stuart Mill, marginalia, Alexis de Tocqueville, Auguste Comte, histoire intellectuelle, humanités numériques, développement de projet

Keywords: John Stuart Mill, marginalia, Alexis de Tocqueville, Auguste Comte, intellectual history, DH project development

\section{AUTHOR}

\section{ALBERT D. PIONKE}

Université d'Alabama, États-Unis 